\title{
Enzyme immunoassay for the detection of Chlamydia trachomatis antigen in urethral and endocervial swabs
}

\author{
GILANFAR MUMTAZ, BJ MELLARS, GL RIDGWAY, JD ORIEL* \\ From the Departments of Clinical Microbiology and *Genito-urinary Medicine, University College Hospital, \\ London WC1
}

SUMMARY An enzyme immunoassay technique based on the direct detection of Chlamydia trachomatis antigen in urethral or cervical swabs was used for the rapid diagnosis of chlamydial genital infection. Urethral and cervical samples from 140 patients were tested in parallel by enzyme immunoassay and cell culture using iodine staining. The direct test had a sensitivity of $92.5 \%$ and specificity of $97.2 \%$ when compared with the cell culture system. The enzyme immunoassay technique provides a rapid and simple method for diagnosing chlamydial genital infection and may be performed on a large number of samples in laboratories which do not have tissue culture facilities or a trained microscopist.

Chlamydia trachomatis is the commonest cause of preventable blindness in the world. ${ }^{\prime}$ It is also an important genital pathogen of men and women and may cause ophthalmia neonatorum and respiratory infection in neonates. Lower genital tract infections in both sexes may be followed by serious complications such as epididymitis, pelvic inflammatory disease (with the attendant risk of infertility), and perihepatitis. Even mild and asymptomatic infections with $C$ trachomatis may have serious consequences and early diagnosis and treatment is clearly important.'

The traditional method for detecting $C$ trachomatis entails the use of tissue cultures grown on coverslips in vials or microtitre plates followed by staining with iodine, Giemsa stain, or fluorescent antibody dyes. These techniques are expensive, laborious, and time consuming, requiring strict quality control of both the cell line and the media. Recently, a direct (culture independent) immunoflourescence test for the diagnosis of $C$ trachomatis has been described. ${ }^{23}$ The test uses a monoclonal antibody and has both high sensitivity and specificity. This direct technique is based on the detection of extracellular $C$ trachomatis elementary bodies. Although simple and rapid, the test is technically demanding and the skill of the microscopist plays a major part in its sensitivity and specificity. ${ }^{2}$

Accepted for publication 19 March 1985
We describe here an enzyme immunoassay technique (Abbott Laboratories) for the rapid detection of $C$ trachomatis antigen in urethral and cervical specimens. The immunoassay technique has been compared with an established cell culture technique in routine use in this laboratory.

\section{Material and methods}

PATIENTS

All the patients attended the Department of Genito-urinary Medicine, University College Hospital, London. Endourethral swabs from 61 men with non-gonococcal urethritis and cervical swabs from 79 women who were contacts of men with nongonococcal urethritis were studied. Patients who had received antimicrobial chemotherapy during the previous four weeks were excluded. Endourethral specimens were obtained by inserting a cotton wool tipped wire swab 4-5 cm into the urethra; cervical swabs were taken with a cotton wool tipped wooden swab rotated in the cervical canal.

\section{SPECIMENS}

Two swabs were collected from each patient. One was inserted into the Abbott's enzyme immunoassay transport medium and the other was taken into a chlamydial transport medium.' ${ }^{\prime}$ Swabs were placed first or second into the transport media in a known but unpredictable sequence according to a random number table; this avoided bias of the identification system associated with the quality of specimens. 


\section{CHLAMYDIA CULTURE}

Monolayer preparations of McCoy cells were prepared in Eagle's minimum essential medium with $10 \%$ fetal calf serum on glass coverslips in plastic tubes. Specimens were collected into chlamydial transport medium consisting of the mimimum essential medium growth medium plus $1 \% 3 \mathrm{M}$ glucose, gentamicin $(10 \mu \mathrm{g} / \mathrm{ml})$, vancomycin $(10 \mu \mathrm{g} / \mathrm{ml})$, and amphotericin B $(2 \cdot 5 \mu \mathrm{g} / \mathrm{ml}){ }^{1}$

To culture the organism the supernatant growth medium was removed from the coverslip preparation and the cells were treated with cycloheximide at a final concentration of $1 \mu \mathrm{g} / \mathrm{ml} .^{4}$ After treatment, $0.5 \mathrm{ml}$ of infected chlamydial transport medium was added to each of two coverslip preparations.

The inoculated cells were then centrifuged at $3000 \mathrm{~g}$ for $1 \mathrm{~h}$ at $33^{\circ} \mathrm{C}$ and this was followed by incubation at $36^{\circ} \mathrm{C}$ for up to to $72 \mathrm{~h}$. After incubation one of the pair of tubes was removed and the cells were fixed with neat methanol for $10 \mathrm{~min}$, stained with Lugol's iodine for $5 \mathrm{~min}$, blotted, dried, and mounted. Slides were examined by bright field microscopy for the presence of the distinctive brown inclusion bodies. The number of inclusion forming units seen per low power field using a $\times 16$ objective was estimated. Cells from the remaining tube were passaged into fresh cells. The cells were then centrifuged, and the supernatant medium replaced with $1 \mathrm{ml}$ of fresh chlamydial transport medium containing $1 \mu \mathrm{g} / \mathrm{ml}$ of cycloheximide. Tubes were incubated and examined in the same manner as the orginal tube.

\section{ENZYME ASSAY PROCEDURE}

Samples were collected from the patient into the transport medium supplied by Abbott Laboratories. Specimens were examined within $72 \mathrm{~h}$ of collection after storage at $+4^{\circ} \mathrm{C}$.

Before testing, $1 \mathrm{ml}$ of specimen dilution buffer (supplied with the kit) was added to each specimen tube, which was then left at room temperature for $10 \mathrm{~min}$. Samples were then vortex mixed three times for $15 \mathrm{~s}$ each time on a Fisons Whirlimixer at maximum setting. All samples and controls were treated in this manner. After mixing, the liquid in the swab was expressed by pressing and rotating it against the side of the tube; the swab was then discarded. Immediately after this procedure the samples were assayed.

\section{Assay}

Two hundred microlitres of sample or control specimen was pipetted into one well of a plastic reaction tray, to which was added a commercially prepared polystyrene bead labelled with polyclonal antibody to $C$ trachomatis. One positive and three negative control specimens (supplied with the kit) were included with every run. After sealing, the tray was incubated at $37^{\circ} \mathrm{C}$ for $45 \mathrm{~min}$. The beads were then washed three times in distilled water using an Abbott Pentawasher. Two hundred microlitres of rabbit serum containing antibody to $C$ trachomatis was added to each bead, and the plate was resealed and reincubated at $37^{\circ} \mathrm{C}$ for a further $45 \mathrm{~min}$. The beads were washed again three times in distilled water, and then $200 \mu \mathrm{l}$ of horseradish peroxidase conjugated goat serum containing antibodies to rabbit IgG was added to each bead. Plates were resealed and reincubated at $37^{\circ} \mathrm{C}$ for a further $45 \mathrm{~min}$. After three further washes in distilled water the beads were transferred to clean, clear plastic tubes (supplied with the kit) and $300 \mu$ l of substrate (ophenylenediamine $2 \mathrm{HCl}$ prepared in citrate phosphate buffer with $0.02 \%$ hydrogen peroxide) was added to each tube containing a bead and to two further clean tubes to act as substrate blanks. All tubes were left in the dark at room temperature for $30 \mathrm{~min}$, after which the reaction was stopped by the addition of $1 \mathrm{ml}$ of $1 \mathrm{~N}$ sulphuric acid to each tube.

Tests were read on a Quantum spectrophotometer at $492 \mathrm{~nm}$. Negative controls were required to have an absorbance of less than 0.150 and positive controls an absorbance of greater than 0.800 to validate the test. Samples from patients giving an absorbance of greater than $0 \cdot 100$ plus the negative control value were considered reactive. Samples were retested if the reading fell within $20 \%$ of the gross cut off range (determined as $0 \cdot 100$ plus the average negative reading).

Cell culture and enzyme immunoassay were carried out by different personnel in order to avoid bias in interpretation.

Statistical correlates were determined using the $\chi^{2}$ test with Yates' correction.

\section{Results}

$C$ trachomatis was isolated from $27 \cdot 1 \%$ of samples $(38 / 140)$, which corresponds to an isolation rate of $15.2 \%(12 / 79)$ for women and $42.6 \%(26 / 61)$ for men. The number and percentage of positive specimens using the enzyme immunoassay system were $15.2 \%(12 / 79)$ for women and $41 \%(25 / 61)$ for men. The Table shows results obtained by both culture and the enzyme immunoassay system. There were five discordant results. Two of these were positive by enzyme immunoassay and negative by culture (one man and one woman). Conversely, there were three culture positive samples which were negative by enzyme immunoassay (one woman and two men). Two of the optical density values for enzyme immunoassay negative specimens showing 
Positive and negative results obtained by enzyme immunoassay and cell culture of specimens from 61 men and 79 women

\begin{tabular}{lrlllll}
\hline & \multicolumn{2}{l}{ Positive } & & \multicolumn{2}{l}{ Negative } \\
\cline { 2 - 3 } \cline { 5 - 6 } & Men & Women & & Men & Women \\
\hline $\begin{array}{l}\text { Results of enzyme } \\
\text { immunoassay: }\end{array}$ & 24 & $11^{*}$ & & 1 & 1 \\
$\begin{array}{l}\text { Positive } \\
\text { Negative }\end{array}$ & 2 & 1 & & 34 & 66 \\
\hline
\end{tabular}

${ }^{*}$ One woman positive on passage only.

discordance (culture positive, enzyme immunoassay negative) were well below the retest range, and one which fell within the retest range initially had a low optical density value when retested. One of the enzyme immunoassay positive specimens showing discordance (culture negative, enzyme immunoassay positive) gave an optical density value within the retest range when the test was repeated.

\section{Discussion}

The high sensitivity and specificity values found by enzyme immunoassay compared with the culture system were impressive. There were only two possible false positive results obtained by enzyme immunoassay which could not be confirmed by culture (1.4\% of total number). These may have been because of the presence of non-viable antigenic material in the specimen or may have resulted from the presence of some interfering agents in the enzyme immunoassay test system. On the other hand, there were three definite false negative results found by enzyme immunoassay $(2 \cdot 1 \%$ of total number). In these three cases the initial inoculum gave $<1$ inclusion forming units per low power field $(\times 16$ objective) and the second swab had been used for culture. The order in which the first or second swab was used for either system did not make a significant difference to the results obtained for specimens from men or women $(p>0.5$ for men and $p>0 \cdot 1$ for women).

It is reasonable to compare the results obtained from the initial inoculation in the culture system with the enzyme immunoassay result because in most diagnostic laboratories only one tube is usually set up for culture as duplication of the culture system and subsequent passage is expensive and time consuming. Passage yielded only one further positive culture. When compared with the enzyme immunoassay system the results from the initial inoculum showed an overall sensitivity of $92.5 \%$ and specificity of $97.2 \%$. The enzyme immunoassay system was slightly more sensitive for urethral specimens from men $(92.6 \%$ for men and $92.3 \%$ for women) but had a higher specificity for cervical specimens (98.5\% for women, $97.3 \%$ for men). This difference was not significant $(p>0 \cdot 5)$.

The sensitivity and specificity of the enzyme immunoassay method found in this study are comparable to the results obtained by Jones et al, ${ }^{5}$ who obtained a sensitivity of $81 \%$ and a specificity of $98 \%$ during phase II of their study using a modified enzyme immunoassay kit similar to the kit evaluated by us.

The results obtained with the Abbott's enzyme immunoassay system for the detection of $C$ trachomatis antigen are encouraging. Although there is some scope for improvement of the sensitivity of the enzyme immunoassay test, it proved to be a simple and rapid diagnostic technique, taking only three and a half hours to perform, which could easily be used to process a large number of samples.

\section{References}

' Oriel JD, Ridgway GL. Genital infection by Chlamydia trachomatis. London, Edward Arnold, 1982.

2 Tam MR, Stamm WE, Hansfield HH, et al. Culture independent diagnosis of Chlamydia trachomatis using monoclonal antibodies. $N$ Engl J Med 1984;310:1146-50.

${ }^{3}$ Thomas BJ, Evans RT, Hawkins DA, Taylor-Robinson D. Sensitivity of detecting $C$ trachomatis elementary bodies in smears by use of a fluorescein labelled monoclonal antibody: comparison with conventional chlamydial isolation. J Clin Pathol 1984;37:812-6.

${ }^{4}$ Ripa KT, Mårdh PA. Cultivation of C trachomatis in cycloheximide-treated McCoy cells. J Clin Microbiol 1977;6:328-33.

5 Jones MF, Smith TF, Houglum AJ, Herrmann JE. Detection of Chlamydia trachomatis in genital specimens by Chlamydiazyme test. J Clin Microbiol 1984;20:465-7.

Requests for reprints to: Mrs G Mumtaz, Department of Clinical Microbiology, University College Hospital, Grafton Way, London WC1E 6AU, England. 